\title{
Isolation of Atypical Lipopolysaccharides from Purified Cell Walls of Pseudomonas cepacia
}

\author{
By J. M. MANNIELLO, H. HEYMANN AND F. W. ADAIR \\ Research Department, Pharmaceuticals Division, CIBA-GEIGY Corporation, \\ Summit, New Jersey 07901, U.S.A.
}

(Received 28 November 1978)

\begin{abstract}
Wall fragments were prepared from two strains of Pseudomonas cepacia and from P. aeruginosa, and their contents of readily extractable lipid, pronase-digestible protein and lipopolysaccharide were measured. Lipopolysaccharide extracted from $P$. cepacia, although biologically active, contained no detectable 2-keto-3-deoxyoctonic acid, but contained phosphate, rhamnose, glucose, heptose and hexosamine in concentrations comparable to those found in $P$. aeruginosa.
\end{abstract}

\section{INTRODUCTION}

Pseudomonas cepacia, originally described as a plant pathogen (Ballard et al., 1970), has been implicated in nosocomial infections with increasing frequency (Gelbart et al., 1976; Bassett et al., 1973). The organism is more resistant than other Gram-negative bacteria to quaternary ammonium compounds and most chemotherapeutically useful antimicrobial agents. The relationship between the chemical nature of the cell wall and antimicrobial resistance has long been established (for reviews, see Brown, 1975; Hamilton, 1971). While the walls of Salmonella typhimurium, Escherichia coli and Pseudomonas aeruginosa have been well-characterized, relatively little is known about the walls of $P$. cepacia. In this paper, we describe the composition of the walls of two typically resistant strains of $P$. cepacia and the isolation of an atypical lipopolysaccharide (LPS) from four such strains.

\section{METHODS}

Organisms. Pseudomonas cepacia 153, originally received from Dr G. L. Gilardi, Hospital for Joint Diseases, New York, N.Y., U.S.A., was maintained in the CIBA-GEIGY culture collection. Pseudomonas cepacia ATCC 25416 and $P$. aeruginosa ATCC 9027 were obtained from the American Type Culture Collection. Clinical isolates ( $P$. cepacia 2013-75, 1942-75) were obtained from Dr M. Moody, Baltimore Research Center, N.C.I., Baltimore, Md, U.S.A.

Media and growth. Organisms were cultured in a semi-defined glucose/Casamino acids (Difco)/salts medium (Adair et al., 1971) at $30^{\circ} \mathrm{C}$ without shaking.

Reagents. Bovine pancreatic ribonuclease A (71 Kunitz units $\mathrm{mg}^{-1}$ ), 2-thiobarbituric acid and 2-keto-3deoxyoctonate (KDO) ammonium salt were obtained from Sigma. Glucoheptose (D-glycero-D-guloheptose) was purchased from Research Plus Laboratories, Dover, N.J., U.S.A. Pronase (45000 proteolytic units $\mathrm{g}^{-1}$ ) was obtained from Calbiochem. Glucostat (special reagent) was purchased from Worthington Biochemical Corporation, Freehold, N.J., U.S.A. 1-Ethyl-2-[3-(1-ethylnaphtho[1,2-d]thiazolin-2-ylidene)-2-methylpropenyl]naphtho[1,2-d]thiazolium bromide was purchased from Eastman Organic Chemicals Co., Rochester. N.Y., U.S.A.

Preparation of wall fragments. Batches $(201)$ of cells were harvested by centrifugation $(7000 \mathrm{~g})$ and washed twice with distilled water. Packed cells were stored frozen at $-10^{\circ} \mathrm{C}$. They were thawed and suspended in distilled water for breakage by high-frequency sound in a Sonifier Cell Disruptor (model W185D; Heat Systems-Ultrasonics, Plainview, N.Y., U.S.A.). Treatment for $3 \mathrm{~min}$ at maximum power, applied as $60 \mathrm{~s}$ 
bursts with interspersed 1 min cooling intervals, resulted in $100 \%$ breakage, as observed by phase contrast microscopy. Broken preparations were centrifuged at $3500 \mathrm{~g}$ for $10 \mathrm{~min}$; the supernatant was removed and centrifuged at $30000 \mathrm{~g}$ for $30 \mathrm{~min}$, yielding a pellet of cell wall fragments (CWF) which was washed once with distilled water, resuspended in distilled water and treated with bovine pancreatic RNAase ( 3 to $5 \mathrm{mg}$ per $\mathrm{g}$ wet wt cells before breakage) for $20 \mathrm{~h}$ at $37^{\circ} \mathrm{C}$. The RNAase-treated CWF were washed with distilled water, until the absorbance at $260 \mathrm{~nm}$ of the supernatant was less than 0.01 on successive centrifugations, and then lyophilized.

Sequential determination of the gross composition of wall fragments. The readily extractable lipid and pronase-digestible protein fractions of CWF were determined by difference after extraction or digestion. Readily extractable lipids were removed by extraction with chloroform/methanol. CWF (100 mg) were stirred at room temperature for $2 \mathrm{~h}$ with $15 \mathrm{ml}$ chloroform/methanol $(2: 1, \mathrm{v} / \mathrm{v})$. The suspension was either carefully filtered or centrifuged for $15 \mathrm{~min}$ at $27000 \mathrm{~g}$ with the supernatant being removed by suction. The residue was re-extracted as before and dried to constant weight. The delipidated material was treated with pronase (Chester \& Murray, 1975), and then washed twice with distilled water and dried to constant weight. Lipopolysaccharide was extracted with hot phenol (Westphal \& Jann, 1965). All fractions from this procedure were collected and dialysed extensively against running tap water and then distilled water to remove the phenol. After dialysis, the phenol extract was centrifuged at low speed to remove particulate material that had appeared during dialysis. This material was added to the residue fraction. The water and phenol fractions were centrifuged at $105000 \mathrm{~g}$ and the pellets were dried to constant weight.

Methods of qualitative analysis. The major sugar components of LPS were identified by means of paper chromatography. LPS ( 1 to $5 \mathrm{mg}$ ) was hydrolysed in $1 \mathrm{M}-\mathrm{HCl}$ for $1 \mathrm{~h}$ at $100^{\circ} \mathrm{C}$ and the hydrolysate was extracted with chloroform to remove lipid components. The partially degraded polysaccharide fraction was further hydrolysed for $4 \mathrm{~h}$ in $1 \mathrm{M}-\mathrm{HCl}$ at $100^{\circ} \mathrm{C}$. Acid was removed either by ion exchange resin or repeated evaporation in vacuo. Descending paper chromatography was performed using Whatman no. 1 paper and the following solvent systems: (A) butan-1-ol/acetic acid/water (4:1:5, by vol.); (B) butan-1-ol/ethanol/ water (12:8:4, by vol.) and (C) butan-1-ol/pyridine/water (6:4:3, by vol.). For visualization of the spots, alkaline silver nitrate (Trevelyan et al., 1950), p-anisidine (Hough et al., 1950) or ninhydrin were used.

The thin-layer chromatographic method of Buttke \& Ingram (1975) was used to identify lipid A in the chloroform fraction. A chloroform extract from hydrolysed $E$. coli LPS was used as a standard.

Methods of quantitative analysis. Pentoses, methyl pentoses and hexoses were measured by the appropriate cysteine-sulphuric acid methods of Dische, as described by Ashwell (1957). Heptose was determined by the Dische cysteine-sulphuric acid method, as modified by Wright \& Rebers (1972). D-Glucose was analysed, using glucose oxidase (Glucostat), after hydrolysis with $1 \mathrm{~m}-\mathrm{HCl}$ for $4 \mathrm{~h}$ at $100{ }^{\circ} \mathrm{C}$ and subsequent neutralization with a weak base ion-exchange resin. KDO was determined according to Osborn's modification of the method of Weissbach \& Hurwitz (Osborn, 1963) and by the newer modification of this method developed by Karkhanis et al. (1978). The method of Ghuysen et al. (1966) which includes a 4 h hydrolysis with $3 \mathrm{M}-\mathrm{HCl}$ was used to determine total hexosamines. A modified version of the Martin-Doty procedure (Heymann et al., 1967) was used for the determination of phosphorus. The carbocyanine dye procedure of Janda \& Work (1971) was used to identify and quantify the LPS preparations. Spectra were determined on a Beckman DU spectrophotometer.

Determination of biological activity. Samples of the various fractions extracted according to the Westphal procedure were assayed for pyrogenic activity, according to the standard United States Pharmacopeia XIX pyrogen test, using rabbits as the test animal (United States Pharmacopeia Convention Inc., 1974).

\section{RESULTS AND DISCUSSION}

Difficulty in extracting LPS from whole bacteria or purified wall fragments of $P$. cepacia led us to adopt the fractionation scheme outlined in Methods. We thus obtained information on the gross composition of the cell wall of these organisms as well as LPS pure enough for chemical analysis.

The wall of $P$. cepacia was grossly similar to that of other Gram-negative organisms of which $P$. aeruginosa is considered representative (Table 1 ). However, LPS from $P$. cepacia differed in several respects. It distributed into both phases of the Westphal extraction. We believe that the extracted material is LPS because it was pyrogenic in rabbits and reacted with a carbocyanine dye to produce a spectral shift specific to LPS. The composition of the isolated LPSs is shown in Table 2. Compared with LPS from P. aeruginosa, that from both strains of $P$. cepacia had less phosphorus and more heptose. Glucose and rhamnose were 
Table 1. Gross composition $(\%, w / w)$ of cell wall fragments

\begin{tabular}{|c|c|c|c|c|c|c|}
\hline \multirow[b]{2}{*}{ Strain } & \multirow{2}{*}{$\begin{array}{c}\text { Readily } \\
\text { extractable } \\
\text { lipid* }\end{array}$} & \multirow{2}{*}{$\begin{array}{l}\text { Pronase- } \\
\text { digestible } \\
\text { protein* }\end{array}$} & \multicolumn{3}{|c|}{ LPS } & \multirow[b]{2}{*}{ Residue } \\
\hline & & & $\begin{array}{r}\text { Water } \\
\text { extract }\end{array}$ & $\begin{array}{l}\text { Phenol } \\
\text { extract }\end{array}$ & Total & \\
\hline $\begin{array}{l}P . \text { aeruginosa ATCC } 9027 \\
P \text {. cepacia ATCC } 25416 \\
P \text {. cepacia } 153\end{array}$ & $\begin{array}{c}14 \cdot 5 \\
7 \cdot 72 \\
11 \cdot 4\end{array}$ & $\begin{array}{l}50 \cdot 5 \\
81 \cdot 0 \\
60 \cdot 8\end{array}$ & $\begin{array}{r}17 \cdot 8 \\
1 \cdot 39 \\
4 \cdot 22\end{array}$ & $\begin{array}{l}1 \cdot 9 \\
3 \cdot 99 \\
4 \cdot 35\end{array}$ & $\begin{array}{c}19 \cdot 7 \\
5 \cdot 38 \\
8.57\end{array}$ & $\begin{array}{c}13 \cdot 2 \\
4 \cdot 22 \\
8 \cdot 30\end{array}$ \\
\hline
\end{tabular}

Table 2. Composition $(\%, w / w)$ of LPS

\begin{tabular}{|c|c|c|c|c|c|c|c|c|}
\hline Strain/extract & $\mathbf{P}$ & $\begin{array}{c}\text { Amino } \\
\text { sugar }\end{array}$ & Heptose & $\mathrm{KDO}$ & Glucose & Pentose & Rhamnose & $\begin{array}{c}\text { Galact- } \\
\text { ose }\end{array}$ \\
\hline $\begin{array}{l}P . \text { aeruginosa } \\
\text { ATCC } 9027 \\
\text { water extract }\end{array}$ & $3 \cdot 25$ & $12 \cdot 2$ & $4 \cdot 05$ & $3 \cdot 34$ & $8 \cdot 1$ & ND & $6 \cdot 4$ & $\operatorname{Tr}$ \\
\hline $\begin{array}{l}P . \text { cepacia } \\
\text { ATCC } 25416 \\
\text { phenol extract }\end{array}$ & $1 \cdot 13$ & $5 \cdot 72$ & $6 \cdot 4$ & ND & $19 \cdot 4$ & $\operatorname{Tr} *$ & $3 \cdot 18$ & ND \\
\hline $\begin{array}{l}P . \text { cepacia } \\
153 \\
\text { water extract }\end{array}$ & $1 \cdot 19$ & $6 \cdot 04$ & $16 \cdot 0$ & ND & $8 \cdot 0$ & $3 \cdot 12 *$ & $4 \cdot 25$ & ND \\
\hline $\begin{array}{l}P . \text { cepacia } \\
153 \\
\text { phenol extract }\end{array}$ & $1 \cdot 18$ & $5 \cdot 02$ & $14 \cdot 0$ & ND & $13 \cdot 05$ & $0.92 *$ & $3 \cdot 7$ & ND \\
\hline
\end{tabular}

ND, Not detectable; $\mathrm{Tr}$, trace (the compound was identified chromatographically but could not be measured).

* Identified chromatographically as xylose.

the major saccharide components of LPS from all organisms. The water and phenol extracts from $P$. cepacia 153 were not strikingly different from each other. KDO was absent from the LPS of the two strains of $P$. cepacia examined in detail. It was also absent from extracts of whole cells of $P$. cepacia 2013-75 and P. cepacia 1942-75. Hurlbert \& co-workers (1976) have reported that the KDO present in LPS from Chromatium vinosum was detected only after a period of hydrolysis five times that needed to liberate the compound from $E$. coli. We have used stronger hydrolytic conditions in our analysis but still found no KDO. In

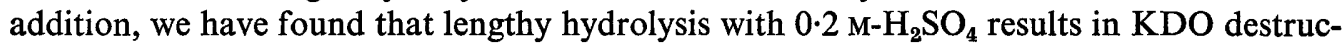
tion. Mild hydrolysis was sufficient to release all the lipid A from $P$. cepacia LPS, as judged by thin-layer chromatography of the chloroform-soluble product. The lipid A was chromatographically similar to that released from $E$. coli under the same conditions.

Although the absence of KDO from LPS is rare, it is not unique. A phenol-soluble, KDO-deficient LPS from Xanthomonas campestris has been reported (Hickman \& Ashwell, 1966). LPS from Spirillum serpens, described by Chester \& Murray (1975), also lacks KDO. There are several reports of organisms with LPS that lacks both KDO and heptose (Adams et al., 1970; Hofstad \& Kristofferson, 1970; Kaspar, 1976). Our findings in conjunction with these others indicate that the prototypical KDO-lipid A linkage found in S. typhimurium (Lüderitz et al., 1973) is not universal.

The authors express their thanks to Mr Jan Bonalsky and Mr John Czekaj who performed the pyrogen tests. 


\section{REFERENCES}

Adair, F. W., Geftic, S. G. \& Gelzer, J. (1971). Resistance of Pseudomonas to quaternary ammonium compounds. II. Cross resistance characteristics of a mutant of Pseudomonas aeruginosa. Applied Microbiology 21, 1058-1063.

Adams, G. A., Quadling, C., Yeguchi, M. \& ToRnABENE, T. G. (1970). The chemical composition of the cell-wall lipopolysaccharides from Moraxella duplex and Micrococcus calco-aceticus. Canadian Journal of Microbiology 16, 1-8.

Ashwell, G. (1957). Colorimetric analysis of sugars. Methods in Enzymology 3, 73-105.

Ballard, R. W., Palleroni, N. J., Doudoroff, M., Stanier, R. Y. \& Mandel, M. (1970). Taxonomy of the aerobic pseudomonads: Pseudomonas cepacia, $P$. marginata, $P$. alliicola, and $P$. caryophylli. Journal of General Microbiology 60, 199-214.

Bassett, P. C. J., Dickson, J. A. S. \& Hunt, G. H. (1973). Infection of Holter-valve by Pseudomonascontaminated chlorhexidine. Lancet i, 1263-1264.

Brown, M. R. W. (1975). The role of the cell envelope in resistance. In Resistance of Pseudomonas aeruginosa, pp. 71-107. Edited by M. R. W. Brown. London: John Wiley.

ButTKe, T. M. \& IngRaM, L. O. (1975). Comparison of lipopolysaccharides from Agmenellum quadruplicatum to Escherichia coli and Salmonella typhimurium by using thin layer chromatography. Journal of Bacteriology 124, 1566-1573.

Chester, I. R. \& Murray, R. G. E. (1975). Analysis of the cell wall and lipopolysaccharide of Spirillum serpens. Journal of Bacteriology 124, 1168-1176.

Gelbart, S. M., Reinhardt, G. R. \& Greenlee, H. B. (1976). Pseudomonas cepacia strains isolated from water reservoirs of unheated nebulizers. Journal of Clinical Microbiology 3, 62-66.

Ghuysen, J.-M., Tipper, D. J. \& Strominger, J. L. (1966). Enzymes that degrade bacterial cell walls. Methods in Enzymology 8, 685-699.

Hamilton, W. A. (1971). Membrane-active antibacterial compounds. In Inhibition and Destruction of the Microbial Cell, pp. 77-93. Edited by W. B. Hugo. New York: Academic Press.

HeymanN, H., Manniello, J. M. \& Barkulis, S. S. (1967). Structure of streptococcal cell walls. V. Phosphate esters in the walls of group A Streptococcus pyogenes. Biochemical and Biophysical Research Communications 26, 486-491.

Hickman, J. \& Ashwell, G. (1966). Isolation of a bacterial lipopolysaccharide containing 3-acetamido-3,6-dideoxy-D-galactose and D-rhamnose. Journal of Biological Chemistry 241, 1424-1428. Hofstad, T. \& KRISTOFFERSON, T. (1970). Chemical characteristics of endotoxin from Bacteroides fragilis NCTC 9343. Journal of General Microbiology 61, 15-19.

Hough, L., Jones, J. K. N. \& Wadman, W. H. (1950). Quantitative analysis of mixtures of sugars by the method of partition chromatography. V. Improved methods for the separation and detection of the sugars and their methylated derivatives on the paper chromatogram. Journal of the Chemical Society, 1702-1706.

Hurlbert, R. E., Weckesser, J., MAYer, H. \& Fromme, I. (1976). Isolation and characterization of the lipopolysaccharide of Chromatium vinosum. European Journal of Biochemistry 68, 365-371.

JANDA, J. \& WORK, E. (1971). A colorimetric estimation of lipopolysaccharides. FEBS Letters 16, 343-345.

KARKHANis, Y. D., Zeltner, J. Y., JACKSON, J. J. \& Carlo, D. J. (1978). A new microassay to determine 2-keto-3-deoxyoctonate in lipopolysaccharide of gram-negative bacteria. Analytical Biochemistry 85, 595-601.

KASPAR, D. L. (1976). Chemical and biological characterization of the lipopolysaccharide of Bacteroides fragilis subspecies fragilis. Journal of Infectious Diseases 134, 59-66.

LÜDERITZ, O., Galanos, C., LehMANN, V., NuRMINEN, M., RIETSCHEl, T. T., ROSENFELDER, G., Simon, M. \& WestPhal, O. (1973). Lipid A: chemical structure and biological activity. In Bacterial Lipopolysaccharides, pp. 9-21. Edited by E. H. Kass \& S. M. Wolff. Chicago: University of Chicago Press.

OsBorn, M. J. (1963). Studies on the gram-negative wall. 1. Evidence for the role of 2-keto-3-deoxyoctonate in the lipopolysaccharide of Salmonella typhimurium. Proceedings of the National Academy of Sciences of the United States of America 50, 499-506.

Trevelyan, W. E., Procter, D. P. \& Harrison, J. S. (1950). Detection of sugars on paper chromatograms. Nature, London 166, 444-445.

United States Pharmacopeia Convention InC. (1974). Pyrogen test. In United States Pharmacopeia $X I X$, p. 613. Easton, Pennsylvania: Mack Publishing Co.

WeSTPHAL, O. \& JANN, K. (1965). Bacterial lipopolysaccharides: extraction with phenol-water and further applications of the procedure. Methods in Carbohydrate Chemistry 5, 83-91.

Wright, B. E. \& Rebers, P. A. (1972). Procedure for determining heptose and hexose in lipopolysaccharides: modification of the cysteine-sulfuric acid method. Analytical Biochemistry 49, 307-319. 